\title{
Inheritance of the Sex-Determining Factor in the Absence of a Complete $Y$ Chromosome in 46,XX Human Males
}

\author{
JOHN R. D. STALVEY AND ROBERT P. ERICKSON \\ Departments of Human Genetics and Pediatrics \\ Univesity of Michigan \\ Ann Arbor, Michigan 48109-0618
}

Sex determination in mammals depends on the presence or absence of a testisdetermining factor (TDF) located on the Y chromosome. In humans, it has been proposed that TDF is localized on the short arm of the Y chromosome. ${ }^{1}$ Approximately 1 in 20,000 phenotypic males have a $46, X X$ genotype $;^{2}$ these men are infertile and have small testes. Many $X X$ males have visible translocations of $Y$ chromosomal material to one of the $\mathrm{X}$ chromosomes. High resolution cytogenetic analyses of these $X: Y$ translocations indicate that the $Y$ fragment is probably a derivative of the tip of the short arm of the $\mathrm{Y}$ chromosome. ${ }^{3}$ Some $46, \mathrm{XX}$ males have no visible translocation, however. Do these individuals also have $\mathrm{Y}$-derived sequences in their genome?

We have studied seven $46, \mathrm{XX}$ males, three with, and four without, visible translocations of $Y$ material, by Southern analysis. The results are summarized in TABLE 1. All six individuals were negative for the $Y$ centromeric probe $Y 97,{ }^{4}$ consistent with the absence of a complete $Y$ chromosome. The genomic probe p75/79 was previously subcloned from cosmid Y75 from a human Y library ${ }^{5}$ and recognizes a $2.0 \mathrm{~kb} E c o R I$ fragment localized on the short arm of the Y chromosome by somatic cell genetics and on the tip of the $Y$ short arm by in situ hybridization. The $3 \mathrm{XX}$ males with visible translocations were positive for the $\mathrm{Y}$ specific $2.0 \mathrm{~kb} E c o R I$ fragment recognized by p75/79. Even in the absence of a visible translocation, DNA from the other $3 \mathrm{XX}$ males also contained the $2.0 \mathrm{~kb}$ Eco $R I$ fragment. In addition, DNA from two XX males with visible translocations was hybridized with $\mathrm{p} 52 \mathrm{~d},{ }^{6}$ which recognizes $Y$ short arm sequences centromeric to $\mathrm{p} 75 / 79$. One is positive, and one is negative for $\mathrm{p} 52 \mathrm{~d}$, indicating that variable amounts of $\mathrm{Y}$ material were translocated. It appears that $\mathrm{XX}$ males inherit a small, though variable portion of DNA from the proximal end of the short arm of the $Y$ chromosome, which appears to contain the sex-determining region. The simple explanation for the mode of inheritance in cases with visible translocation is that $\mathrm{Y}$ material has been added onto the paternal $\mathrm{X}$ chromosome. Could $X X$ males, however, with no visible translocations arise by way of crossing-over between the $X$ and $Y$ chromosome just outside the pseudoautosomal region (a region of shared $X, Y$ homology with one obligate crossover per meiosis), which is located at the proximal end of the $\mathrm{X}$ and $\mathrm{Y}$ short arms? We are currently using a probe localized on the lower boundary of the pseudoautosomal region to investigate this possible mode of inheritance of the sex-determining factor in $46, X X$ human males.

In brief summary, $46, \mathrm{XX}$ males have $\mathrm{Y}$ short arm-derived material containing a presumptive sex-determining factor termed the testis-determining factor, 
TABLE 1. Detection of Y Specific Sequences in 46,XX Males by Southern Analysis with Several Genomic Probes Derived from the Y Chromosome

\begin{tabular}{llllll}
\hline Patient & Karyotype & Y97 $^{b}$ & p75/79 & p52d \\
\hline KWI & $46, X^{a}$ & - & + & + \\
SWE & $46, X^{a}$ & - & + & - \\
GORE & $46, X^{a}$ & - & + & nd $^{c}$ \\
HIN & $46, X X$ & - & + & nd \\
WER & $46, X X$ & - & + & nd \\
GIM & $46, X X$ & - & + & nd \\
DAB & $46, X X$ & - & + & nd \\
\hline
\end{tabular}

a Visible translocation of $\mathrm{Y}$ material.

${ }^{b}$ Y97 detects $Y$ centromeric sequences, whereas p75/79 and p52d detect sequences localized to the proximal short arm of the $Y$ chromosome.

${ }^{c}$ nd $=$ not determined.

whether or not there is a visible translocation of $\mathrm{Y}$ material. The amount of $\mathrm{Y}$ material inherited is variable. The molecular approach provides a very sensitive method for tracking the movement of $\mathrm{Y}$ chromosomal material in 46,XX males.

\section{REFERENCES}

1. Goodfellow, P., S. Darling \& J. Wolfe. 1985. The human Y chromosome. J. Med. Genet. 22: 329-344.

2. De La Chapelle, A. 1972. Analytical Review: Nature and origin of males with XX sex chromosomes. Am. J. Hum. Genet. 24: 71-105.

3. De La Chapelle, A. 1981. The etiology of maleness in XX men. Hum. Genet. 58: 105116.

4. Wolfe, J., S. M. Darling, R. P. Erickson, I. W. Craig, V. J. Buckle, P. W. J. RIGBY, H. F. WiLlaRd \& P. N. GoodFellow. 1985. Isolation and characterization of an alphoid centromeric repeat family from the human T chromosome. J. Mol. Biol. 182: $477-485$.

5. Wolfe, J., R. P. Erickson, P. W. J. Rigby \& P. N. Goodfellow. 1984. Cosmid clones derived from both euchromatic and heterochromatic regions of the human $\mathrm{Y}$ chromosome. EMBO J. 3: 1997-2003.

6. Bishop, C., G. Guellaen, D. Gelwerth, M. Fellous \& J. Weissenbach. 1984. Extensive sequence homologies between $\mathrm{Y}$ and other human chromosomes. J. Mol. Biol. 173: 403-417. 